\title{
Eufrásia Teixeira Leite: personagem biográfica romanceada
}

\author{
Eufrásia Teixeira Leite: biographic character in a novel \\ Marilene Weinhardt \\ Universidade Federal do Paraná, Curitiba, Paraná, Brasil
}

$\diamond$

\begin{abstract}
Resumo: Eufrásia Teixeira Leite (1840-1930) descende da aristocracia brasileira, de família cuja fortuna foi amealhada pela exploração das minas, pela exportação de café e por investimentos em títulos e ações. Sem irmãos do sexo masculino, recebe educação pouco usual para mulheres à época. O pai a inicia no mundo das transações e aplicações de recursos financeiros. Órfã, passa a gerir a herança que cabe a ela e à irmã, mudando-se ambas para Paris. Essa condição privilegiada teve seu custo pessoal. O envolvimento com o político abolicionista Joaquim Nabuco (18491910) limitou-se a encontros rápidos e troca de correspondência. A impossibilidade dessa paixão recíproca chegar à união legal é matéria de dois romances do século XXI, corpus da presente investigação: Mundos de Eufrásia, de Cláudia Lage, (2009), e Um mapa todo seu, de Ana Maria Machado (2015). O objetivo é apreender como se produz o rendimento romanesco a partir dos dados biográficos.
\end{abstract}

Palavras-chave: Romance biográfico; Eulália Teixeira Leite

\begin{abstract}
Eufrásia Teixeira Leite (1840-1930) was a descendant of the Brazilian aristocracy, whose family fortune was gained with mining, coffee and stock investments. With no male siblings, she received an unusual education for women at that time. Once orphan, she was responsible for managing hers and her sister's inheritance. This social and economic privileged position had its personal cost. The involvement with a pro-slavery abolition politician named Joaquim Nabuco (1849-1910) was limited to quick encounters and a long correspondence exchange. The impossibility of turning this passion into legal union is the subject of two recent novels, which compose this work's corpus: Mundos de Eufrásia: a história de amor entre a incrivel Eufrásia Teixeira Leite e o notável Joaquim Nabuco (2009), by Cláudia Lage, and Um mapa todo seu, by Ana Maria Machado (2015). The main goal of this approach is to apprehend the result of biographical data usage in the novel.
\end{abstract}

Keywords: Biographic novel; Eulália Teixeira Leite

\section{Moldura teórica}

A frase "essa vida daria um romance", corriqueira na visão leiga, provocava arrepios de pavor nos leitores profissionais orientados pelas perspectivas formalistas que imperaram no último quartel do século passado. A relação com o referente era ignorada, desprezada. Reação semelhante era manifestada pelos historiadores, à mesma época, diante de registros biográficos que evidenciavam intenções de se inscrever nos arraiais da história como disciplina científica. Os dados factuais não interessavam. Portanto, registros biográficos ficavam à margem dos dois discursos, do literário e do histórico. François Dosse constata que o "caráter híbrido do gênero biográfico" o tornou "sujeito ao opróbrio e a um déficit de reflexão". No entanto, em nenhum momento se deixou de publicar e de ler biografias. Nas palavras do mesmo estudioso, "o gênero biográfico nem por isso deixou de fruir um sucesso público jamais desmentido" (2009, p. 13).

Nestes tempos em que o esfumaçamento de fronteiras não é mais um traço negativo, antes uma constante, tanto mudaram a orientação dos estudos históricos e dos literários, como se multiplicaram e refrataram os relatos de vida. O ensaio citado no parágrafo anterior, cujo jogo entre título e subtítulo já antecipa a concepção da biografia como exercício de escrita e não apenas de pesquisa documental - O desafio biográfico: escrever uma vida -, é pautado pela proposta de preencher o referido déficit. 
Para tanto, traça o percurso do gênero, apreendendo os paradigmas de cada época, e marcando os diálogos com outras áreas do conhecimento que lhe são próprios.

Para a proposta deste estudo, isto é, a apreensão do aproveitamento dos aspectos biográficos em dois romances, por ora releva destacar que, a propósito de recortes e escolhas no trabalho do biógrafo, François Dosse observa a necessidade do jogo entre exclusões e inclusões que denotam o parentesco entre o biográfico e o ficcional. Se, por um lado, "não se abarrotará com o inútill", pelo outro, "deverá, como artista, dar mostras de discernimento e valorizar os fatos significativos que às vezes parecem elementos marginais". Sustentação para esse raciocínio é buscada em concepções de André Maurois: "É mesmo a busca desses detalhes mais anedóticos, porém mais reveladores da personalidade do biografado, que constitui o fascínio e o sentido do gênero biográfico, dependendo portanto, segundo Maurois, da arte do romancista" (DOSSE, 2009, p. 56). Sublinho a ocorrência do termo "artista" e da expressão "arte do romancista". Outro aspecto a destacar na orientação adotada por Dosse diz respeito à noção de verdade: "ao biógrafo não importa muito a verdade: deve, isso sim, criar traços humanos, muito humanos." (p. 57) É mais um ponto a evocar na aproximação entre o biográfico e o romanesco.

Antes ainda de iniciar a anunciada análise das obras literárias, cumpre referir outro estudo que também a baliza. Obra de cariz teórico-analítico sintomática do reconhecimento da atual fusão discursiva é produzida no nosso continente. Mais uma vez, título e subtítulo antecipam a perspectiva subscrita pela autora. Em El espacio biográfico: dilemas de la subjetividad contemporánea (2007), a argentina Leonor Arfuch discute o desenvolvimento e a feição atual desse gênero discursivo, atentando para diferentes manifestações que assume na contemporaneidade, especialmente as diversas formas de entrevistas correntes nestes tempos, conjecturando sobre as razões para sua recorrência e sucesso. A esse propósito, aparece em relevo a noção de subjetividade, tradicionalmente reservada à ficção, subtraída que foi à história e, por extensão, à biografia. Ainda quanto ao título de Arfuch, cumpre destacar a presença em destaque da espacialidade. Trata-se de noção forte ao longo de todo o estudo, não tomando o lugar da temporalidade, mas posta em paralelo a esta, tal como vem acontecendo nas abordagens da narrativa dita ficcional, ou mesmo de toda narrativa, independente do qualificativo que a acompanha.

Superposição, esfumaçamento, fusão eventual, parentesco não significam anulação absoluta de fronteiras. A despeito de tantas aproximações e empréstimos, o gênero biográfico e o gênero romanesco preservam identidade própria. É sempre uma questão de predomínio. Aquele discurso em que as duas presenças estão próximas ao equilíbrio, com discreto predomínio dos efeitos ficcionais, pode ser abordado como romance biográfico. É o modo como se dá essa articulação que se buscará demonstrar em Mundos de Eufrásia, de Cláudia Lage, (2009), e Um mapa todo seu, de Ana Maria Machado (2015).

\section{As personagens referenciais}

A frase entre aspas constante no primeiro parágrafo deste texto deve ter sido pronunciada muitas vezes em relação à vida da personagem nomeada no título. Seus dados biográficos são encontrados em trabalho histórico de autoria de Neusa Fernandes (2012), obra descrita na sequência.

Eufrásia Teixeira Leite, nascida em 1850 e falecida em 1930, descende da nobreza brasileira que sustentou o Império, casta composta por cidadãos detentores de títulos nobiliárquicos alcançados graças ao poder econômico. Membro de família cuja fortuna foi amealhada inicialmente pela exploração de minas de ouro e pedras preciosas, depois incrementada pela produção e exportação do café para, finalmente, ser ampliada em títulos bancários e ações, investimentos que alcançam esfera internacional na fase em que Eufrásia gerencia o capital. Sem irmãos do sexo masculino, essa sinhazinha, que se mostrou uma capitalista de sua época de estatura de Primeiro Mundo, recebeu educação absolutamente inusitada para mulheres de seu tempo. Desde cedo o pai a iniciou nos segredos do universo das transações e aplicações de recursos financeiros. Órfã com pouco mais de 20 anos, passa a administrar a herança que cabe a ela e à irmã, cinco anos mais velha, portadora de defeito físico que a faz puxar uma perna. As duas mudam-se para Paris pouco depois de tomar posse da herança paterna, logo aumentada com o espólio da avó. São poucas as viagens que fazem ao Brasil. O retorno definitivo, depois da morte da irmã Francisca, se dá perto do final da vida da remanescente.

Essa condição privilegiada do ponto de vista social e econômico teve alto custo pessoal. O envolvimento da bela "financista" - para usar termo da época, constante nos romances - com o advogado e diplomata Joaquim Nabuco (1849-1910) - político de intensa atividade em prol da abolição, originário da região que hoje constitui o Nordeste, então apenas Norte - limitou-se a encontros rápidos, breves períodos de convívio e troca de correspondência, por vezes intensa, da qual se conserva boa parte das cartas em que foi ela a emissária e apenas uma dele.

A impossibilidade dessa paixão recíproca chegar à união legal é matéria de dois romances publicados no 
século XXI, corpus da reflexão que ora se apresenta: Mundos de Eufrásia, que traz o subtítulo "a história de amor entre a incrível Eufrásia Teixeira Leite e o notável Joaquim Nabuco", da quase estreante Cláudia Lage - este é seu segundo título romanesco - lançado em 2009, e Um mapa todo seu, de Ana Maria Machado, veterana no gênero ficcional, este de 2015.

Antes de mergulhar nos romances, cabe situar as duas personagens referenciais. Os dados biográficos de Eulália Teixeira Leite, ainda que não sejam necessariamente conhecidos de brasileiros mediamente informados sobre a história do país, não são de acesso difícil. O material disponível está listado na nota final do romance de Ana Maria Machado:

a obra básica e esgotadíssima é a do capixaba José Carlos Bruzzi Castelo, a par de uma amorosa compilação de dados e documentos, muito informativa, Eufrásia Teixeira Leite: Fragmentos de uma existência, de Ernesto José Coelho Catharino, em edição do autor. Muito útil também foi o trabalho de algumas historiadoras que se somaram a Angela Alonso: A sinhazinha emancipada, de Miridan Britto Falci e Hildele Pereira de Melo, bem como Eufrásia e Nabuco, de Neusa Fernandes, além de artigos esparsos publicados em revistas especializadas. E rendo particular homenagem à magnífica reportagem de Marcos Sá Corrêa sobre la, publicada na revista Piauí, um modelo de jornalismo investigativo (MACHADO, 2015, p. 221-222).

A transcrição tem o objetivo de informar sobre as pesquisas existentes e já aproveitar para dizer do modo de coleta de material adotada pela escritora. Como não é objetivo desta abordagem estabelecer distinção entre o que é documentado e o que é ficcionalizado, a leitura desse material ficou restrita ao volume Eufrásia e Nabuco (2012), de Neusa Fernandes, já anunciada fonte das informações biográficas constantes parágrafos acima.

Ainda que sem o intuito de analisar o discurso biográfico como tal, convém comentar a feição geral da obra e as opções escolhidas, para efeitos de eventuais comparações de estruturação.

A historiadora divide a obra em oito capítulos. No primeiro apresenta o espaço de origem, a cidade de Vassouras, desde a ocupação inicial do território até o presente da sua escrita. O segundo capítulo é também dedicado a esse espaço, mas agora quanto a um aspecto socioeconômico específico, a escravidão. Esse detalhamento se justifica quer porque a riqueza da cidade, e do Império mesmo naquele momento, o café, dependia da mão de obra escrava, quer porque a defesa da abolição por parte Joaquim Nabuco é o empecilho central para a união do par. $\mathrm{O}$ terceiro capítulo é dedicado à família Teixeira Leite e o subsequente à biografada. O título dado ao capítulo merece registro, pela forma encontrada para marcar a atipicidade da personagem: "Uma mulher inatual”. O quinto capítulo descreve a constituição e o significado dos dois espaços urbanos escolhidos por Eulália para viver, Paris e Rio de Janeiro. O capítulo seguinte é ocupado pelos desdobramentos das ações decorrentes do testamento da protagonista. O sétimo capítulo é dedicado ao percurso de Joaquim Nabuco, identificado desde o título como "um homem paradoxal". Esse capítulo, ainda que breve, apresenta estrutura independente. Até essa altura a relação amorosa aparece incidentalmente, o nome de um aparecendo na vida do outro de modo quase casual, reservando-se o enredo amoroso para o derradeiro capítulo, sob o título "Um romance entre farpas e beijos". O leitor interessado no plano afetivo pode fazer a leitura deste capítulo exclusivamente, complementado por um quadro intitulado "Cronologia - Eufrásia e Nabuco", que aparece depois da conclusão, registrando o ano em que "reatam" ou "desmancham", namoro ou noivado, conforme a fase do relacionamento, além de nascimentos e mortes, viagens e atividades mais relevantes do cidadão e político Nabuco (FERNANDES, 2012, p. 145).

A edição em capa dura é fartamente ilustrada. Além das previsíveis imagens dos biografados e dos espaços em que viveram, traz quadros com resultados de recenseamentos e listagens de negros condenados por rebelião, de modo a delinear o cenário da sociedade brasileira da época. Mais da metade do volume é ocupada por Anexos. O Anexo I, longo, reproduz os originais das cartas, devidamente transcritas. O Anexo II contém a "Relação das Obras da Biblioteca da Casa da Hera", (FERNANDES, 2012, p. 307) informação de interesse para a história da vida privada e para auxiliar a percepção da formação da personagem. O Anexo III é constituído pela "Transcrição do discurso de posse de Joaquim Nabuco no Instituto Histórico e Geográfico Brasileiro, em 25 de outubro de 1896". (FERNANDES, 2012, p.327), dando conta, portanto, de alguns aspectos dessa personagem, concomitantemente a informações históricas sobre discussões em curso na época.

$\mathrm{O}$ nome do abolicionista Joaquim Nabuco tem grande repercussão na história do país. A título de exemplificação, considere-se sua presença em duas obras históricas recentes, ambas cobrindo os cinco séculos de existência do país. Em História do Brasil: uma interpretação (2008), de Adriana Lopes e Carlos Guilherme Mota, no Índice Onomástico há vinte registros de Joaquim Nabuco (p. 1050). Em Brasil: uma biografia (2015), de Lilia M. Schwarcz e Heloisa M. Starling, são oito ocorrências. Ainda que dados quantitativos pouco signifiquem para o tipo de trabalho que se intenta aqui, uma vez que se está buscando evidenciar a marca que Joaquim Nabuco deixou na história do Brasil, vale 
considerar que uma figura como Rui Barbosa totaliza vinte e oito registros na primeira obra e também oito na segunda. Quando a dados biográficos especificamente, o próprio Joaquim Nabuco deu contribuição significativa, na forma de obra autobiográfica, Minha formação (1900), de diários e de vasta e variada correspondência, material hoje devidamente publicado. Ana Maria Machado aponta como "indispensáveis pelo menos três biografias [...] - as escritas por sua filha Carolina, pelo acadêmico Luís Viana Filho e a recente e fascinante obra da historiadora Angela Alonso" (MACHADO, 2015, p. 221);

A abordagem que segue não tem como linha mestra a busca sobre o quanto e como os dados históricos aparecem no plano ficcional, embora não se esqueça que se tratam de romances biográficos e como tal devem ser estudados. O que se intenta observar é como a situação histórico-biográfica é apropriada por duas escritoras, no século XXI, mulheres que produzem obras que podem ser lidas, conforme se buscará demonstrar, como focalização e discussão sobre o estatuto da mulher na sociedade brasileira, remontando, para tanto, a outro tempo, passado individual que reflete, condiciona e é condicionado pelo passado histórico.

\section{Eulália heroína}

Em obediência à cronologia de publicação, começa-se pelo romance de Cláudia Lage, Mundos de Eufrásia, de 2009. O termo escolhido para o título - mundos, no plural - remete a vários níveis de duplicidade presentes no enredo: mundo pessoal e mundo social, o primeiro refratando-se em familiar e afetivo, o segundo bipartindo-se em cotidiano em sociedade e atividade financeira; ou ainda, mundo nacional e mundo internacional, o primeiro marcando geograficamente início e fim de vida, o segundo comportando o apogeu econômico e a paixão amorosa. O fio que sustenta a ação romanesca é o conflito entre o mundo em que foi dado a Eufrásia viver e a educação que recebeu, aliada à sua capacidade intelectual. O longo subtítulo, que pela construção apelativa poderia ser uma chamada de capa, um recurso editorial - A história de amor entre a incrível Eufrásia Teixeira Leite e o notável Joaquim Nabuco consta também na página de rosto e na ficha catalográfica, indicando tratar-se de direcionamento de leitura proposto pela voz autoral. Ecoa o tempo figurado, nessa forma anacrônica, e antecipa a singularização das personagens, nos adjetivos.

O volume, dividido em blocos curtos, sem título e sem numeração, cada um ocupando de duas páginas até uma dezena, comporta o que se pode perceber desde logo como dois conjuntos, duas narrativas, diferenciadas pelos tipos gráficos, compondo o romance. Uma narrativa é constituída por quatro blocos breves, três na abertura e um conclusivo. Nesta parte a voz narradora é em primeira pessoa, em tempo que se depreende ser o presente da escrita. Esse "eu" se apresenta como alguém que está distraída, pelo hábito de começar a devanear quando o tema é morte. É o que está acontecendo naquela situação, quando percebe que, precisamente no momento em que ela, narradora, estava pensando em formigas, em como não é capaz de lhes fazer mal, as pessoas que falam ao seu lado, justamente a conversa da qual sua atenção se evadira por causa do assunto, mencionam formigas. Referem-se a uma mulher, já idosa, que não queria que se exterminassem as formigas que infestavam seu jardim e até sua casa. Passando a prestar atenção na conversa e até fazendo indagações, a narradora fica inteirada das circunstâncias da vida dessa mulher, sintetizada em "foi uma moça belíssima [...] e muito rica. Mais do que isso, que era dona do próprio nariz, em pleno século XIX" (LAGE, 2009, p. 22). Diante de sua curiosidade, alguém informa sobre a existência de "um romance publicado sobre a vida dessa jovem, a senhora de oitenta anos," finalmente nomeada: Eufrásia Teixeira Leite. Essa voz narrativa só retorna no último bloco: "quando terminei de ler o livro..." (LAGE, 2009, p. 417) Portanto, o que lemos é o livro lido por tal narradora. Ou seja, o recurso narrativo é encaixar a narrativa supostamente já existente no relato de um episódio contemporâneo. Atentar para mais um trecho do conjunto introdutório antecipa o centro em torno do qual gira o dito livro lido: "quem contou a história afirmou [...] sussurrando, dona do próprio corpo também. Algumas pessoas se alvoroçaram, querendo saber como, quando, com quem? [...] Era o próprio século XIX que desabava sobre nossas cabeças" (LAGE, 2009, p. 22).

A narrativa encaixada, em terceira pessoa, ocupando quase a totalidade das mais de quatro centenas de páginas do volume, responde a todas essas perguntas em detalhes, faz com que o século XIX desabe sobre a cabeça de todos nós, leitores. Circula com igual desenvoltura nas ações e no interior de todas as personagens. Essa onisciência é respaldada em concepção sobre ficção e realidade explicitada no último bloco, aquele que integra e completa a primeira narrativa. No romance figurado como a narrativa lida pela narradora explícita, a correspondência entre os dois amantes é colocada na urna mortuária, sob o corpo de Eulália, portanto enterrada com ela. A narrativa em primeira pessoa dá conta de outra versão:

Eufrásia não tivera a coragem de incendiar as próprias lembranças, disseram, e fizera o pedido à fiel Cecilia. $\mathrm{O}$ fogo sobre as palavras, disseram, e não o corpo. Não as cartas no caixão, sob o peso de pele e órgãos, 
envolvidos pela terra escura. Escuto, o libro aberto à minha frente. As minhas mãos sobre a última página. Ressoa entre os meus dedos o encontro da carne com a celulose, enquanto o cheiro de papel queimado toma o ambiente, cintila em minha pele, invade minhas narinas. São as duas possibilidades verdadeiras, digo, as duas verdades, ficção. Não acredito que a realidade é essa máscara de uma só face. Para mim, a realidade é apenas a ficção que nos acontece. Sonho ou pesadelo de nossos dias. E me acontece a sensação nos dedos, me acontece o cheiro. Minhas mãos tensas sobre a celulose. A brasa ardida no ar (LAGE, 2009, p. 417).

Sob esse signo é criada a realidade de Eulália, sem conjecturas, sem hesitações.

Antes de seguir a caracterização da personagem, abre-se parênteses para comentário marginal. Na biografia de Neusa Fernandes já abordada, as "Conclusões" iniciam com explicações sobre a correspondência entre Eulália e Nabuco, referindo período de duração e onde está o que se preservou. O segundo parágrafo informa: "O desaparecimento das cartas enviadas por ele à Eufrásia explica-se: foram incineradas pelo seu testamenteiro, cumprindo seu desejo." Informação factual, como definitiva. Entretanto, o parágrafo seguinte traz outra versão, apoiada em mais de uma fonte:

Segundo o jornalista Moacyr Werneck, antes de morrer Eufrásia pediu ao advogado Raul Fernandes [...] que enterrasse com ela todas as cartas que recebera de Joaquim Nabuco. Tal fato foi confirmado por Gilberto Freyre, que acreditava que o advogado cumprira fielmente a vontade da benemérita de Vassouras; ainda o historiador Américo Jacobina Lacombe afirmara ter ouvido do próprio advogado que destruíra toda a correspondência (FERNANDES, 2012, p. 141).

Note-se que o romance em discussão é publicado antes desse texto histórico, embora as fontes citadas pela historiadora já pudessem estar disponíveis. Cláudia Lage não explicita a documentação a que recorreu, diferentemente da atitude de Ana Maria Machado, conforme já citado. Estes comentários não tem o intuito de comportar qualquer achega à discussão sobre o conceito de criação que preside o romance. Apenas uma curiosidade para sublinhar a fluidez da realidade.

Retomando a sequência discursiva do romance em pauta, vale notar que a realidade de Eufrásia é antecipada nos versos de Cecília Meireles escolhidos para epígrafe: "Não posso mover meus passos/ Por esse atroz labirinto/ De esquecimento e cegueira/ Em que amores e ódios vão". Limitações, esquecimento, amores e ódios condutores da vida da personagem são reforçados em segunda epígrafe, uma linha de Caio Fernando Abreu que diz do vazio, incompreensível e vão: "Era escuro e rouco como as coisas que não têm depois" (LAGE, 2012, s/p).
Há mais a comentar sobre uso de epígrafe. A cena que abre a narrativa sobre o passado, no momento em que Eulália e a irmã Francisca são chamadas para a cabeceira do pai moribundo, traz epígrafe contemporânea da ação, versos de Castro Alves sobre errância, efemeridade e esquecimento: "Ó espíritos errantes sobre a terra! Ó velas enfunadas/ sobre os mares!... Vós bem sabeis quanto sois efêmeros... - passageiros que vos absorveis no espaço escuro,/ ou no escuro esquecimento" (LAGE, 2012, p. 23).

A despeito da onisciência do narrador deste conjunto, o leitor precisa estar alerta para não se sentir perdido no escuro na linha temporal. Esse acontecimento narrado na abertura se dá em 1872, pouco antes do meio do tempo coberto pela narrativa, que se estende por quase um século, desde alguns anos antes do nascimento da heroína até sua morte. Analepses e prolepses embaralham as faixas temporais a tal ponto que é preciso atenção para perceber o avanço da linha narrativa. A narrativa romanesca impera sem concessões. François Dosse enuncia: "A arte biográfica impõe um certo número de cânones. Em primeiro lugar, a biografia deve seguir a ordem cronológica, que permite conservar a atenção do leitor na expectativa de um futuro que desvelará progressivamente o tecido da intriga." (DOSSE, 2009, p. 56) A narradora explícita da primeira narrativa não tivera a notícia da existência de uma biografia, e sim de um romance. Como tal a segunda narrativa se apresenta, um romance nos padrões convencionais do século XIX.

Portanto, não há que estranhar que o uso do termo heroína para a protagonista do romance anunciado como lido não decorra apenas da adoção dessa terminologia, de acordo com a teoria da narrativa romanesca, para designar a personagem feminina principal. A figura é construída por Cláudia Lage como portadora de muitas qualidades positivas: bela, inteligente, investidora sagaz, dama que sabe se comportar nos salões de acordo com seu estatuto social, patroa justa e generosa, filha obediente, irmã dedicada e mulher apaixonada. Seu drama pessoal é a impossibilidade de cumprir esses três últimos papéis concomitantemente.

No leito de morte, o pai, que a preparara para sucessora nos negócios, incutindo-lhe três princípios - a rejeição ao casamento interpares ou intrafamiliar como forma de preservar e aumentar a fortuna; a resistência a entregar a gerência dos bens, na forma de dote, ao marido; a rejeição à tutoria exercida pela família no caso de solteiras órfãs - cria situação que faz com que Eulália se sinta presa à promessa de estar sempre ligada à irmã, protegendo-a. Esta, por sua vez, não perde oportunidade para cobrar fidelidade a tal jura, o que significa não se unir ao amado Joaquim Nabuco, filho de senador do partido liberal, portanto adversário político da família, evidentemente conservadora. Não se trataria, portanto, 
exatamente de união que extrapolasse os limites entre classes sociais, mas entre grupos e interesses políticos. Tanto são do mesmo universo social que se encontraram pela primeira vez ainda na infância, por ocasião da regata em homenagem ao Marquês de Pombal, na enseada do Botafogo, quando as famílias se cumprimentaram e eles ficaram paralisados um diante do outro, a menina impressionada com "aquela criança com olhar de velho" e este com a imagem da "menina à sua frente [...] os fios negros dos cabelos na brisa". (LAGE, 2009, p. 55) Ainda muito jovens se dá um segundo encontro, oportunidade para se reconhecerem como modificados, nem por isso menos interessados mutuamente. Aí começa uma troca de bilhetes, mediada pela mucama que acompanhará Eulália até o enterro. Tais dados são biográficos. O papel do romanesco aparece nas reações, sentimentos e emoções experimentados. O primeiro encontro secreto coincide com o momento em que a mãe dela está morrendo.

Esses dois acontecimentos concomitantes no tempo - o primeiro encontro do par amoroso e a morte da mãe da heroína - são trabalhados de modo a alcançar alta voltagem, repercutindo ao longo de toda a narrativa. A mãe morre repentinamente, angustiada por saber que o pai dá às filhas uma educação que não se coaduna com casamento nos mores da época. Entretanto, esposa conforme o figurino, não ousa contestá-lo. Por sua vez, essa esposa e mãe tem consciência que precisou renunciar a sua individualidade, simbolicamente enterrando o caderno em que registrara suas primeiras sensações e aspirações. Aceita o destino que cabia às mulheres, nem por isso se sente apaziguada. A filha, por sua vez, no momento em que a mãe exala o suspiro derradeiro, sente o gosto do primeiro beijo, "a acidez do abacaxi [...] o cítrico adocicado da lima-da-pérsia” (p.42-43), para sempre os sabores do amado.

Os lances folhetinescos, explorando informações biográficas ou criando situações plausíveis, se sucedem ao longo de toda a narrativa, pontuados com o cuidado e o rigor que merece a escolha de um caso de amor singular como assunto romanesco. O que poderia ser apontado como inverossímil é justamente o que tem comprovação documental: uma mulher, brasileira, no século XIX e no início do século XX, frequentando a bolsa de valores em Paris, gerindo os próprios investimentos e ainda com inegável sucesso. O escândalo de uma relação amorosa que chega ao contato íntimo, de forma mais ou menos pública, sem a proteção do manto matrimonial, parece trazer mais prejuízo, ou pelo menos ser mais explorado na vida política dele do que na imagem social dela, que conta com o escudo da vultosíssima fortuna, fortuna que só faz prosperar. Na descrição dos encontros entre quatro paredes, quase sempre em quartos de hotéis, o erotismo é dosado, de modo a marcar a singularidade dessa mulher, sem resvalar para detalhes de cenas picantes. Preserva-se o pudor do século figurado. As ousadias ficam por conta de outras referências biográficas bem conhecidas, os muitos envolvimentos passionais dele.

Importa sublinhar que os dois homens da vida de Eulália foram homens adiante de seu tempo em vários sentidos. O pai, no plano econômico teve perspicácia para perceber os rumos do capitalismo, os investimentos se impondo sobre a produção. No plano privado, deu instrução a uma filha a ponto de torná-la capaz de circular com desenvoltura em universo que era prerrogativa masculina. $\mathrm{O}$ amado desfraldou a bandeira abolicionista com galhardia, desde quando o movimento ainda não havia tomado corpo em sua esfera social. Entretanto, ambos não só não colaboraram para que ela se realizasse como ser humano, como ainda favoreceram a imposição dos limites representados pela sociedade. O pai, ao the dar educação diferenciada, se lhe deu condições de ser livre financeiramente em relação a marido e família, a condenou à frustração afetiva. $\mathrm{O}$ amado, homem de princípios humanitários que contribuíram decisivamente para a abolição da escravatura, que demonstrava reciprocidade de sentimento na forma como a buscava e tentou o convívio, nem por isso deixou de empreender outras conquistas amorosas de repercussão pública e, principalmente, não foi capaz de superar o julgamento social quando ela impôs, como condição para o casamento, o regime de separação de bens, conforme a tese esposada nessa narrativa. O patriarcalismo tem raízes plantadas tão firmemente que mesmo quando contestado no plano das ideias, por vias por vezes insuspeitas, pode reafirmar sua soberania.

\section{Eulália humanizada}

A proposta de defesa do feminino assumida pela escritora Ana Maria Machado se explicita desde o título, Um mapa todo seu, publicado em 2015, remetendo sem disfarce à ousada militância de Virgínia Woolf, evocada na paráfrase do seu conhecido ensaio de 1929, Um teto todo seu (1985). Concomitantemente, o título inscreve a obra na instância contemporânea, com a remissão à territorialidade. Já se comentou a atualidade desse aspecto, tratando da obra de Leonor Arfuch, cujo primeiro capítulo é justamente intitulado "El espacio biográfico. Mapa del território" (2002, p. 33). O teto do início do século passado se redimensionou e ampliou, alcançando dimensão geográfica, é mapa.

A inscrição na causa feminina se dá em passagem na voz da protagonista, passagem que explica o título: "Ninguém deixou um mapa pronto, a definir esse novo território em que decidi me aventurar [...] estou disposta a arriscar. Posso não ser a primeira pessoa do meu sexo 
nessa procura. [...] deve haver precursoras [...] ainda que não falemos disso umas com as outras [...]. Mas quero estar entre as primeiras" (MACHADO, 2015, p.61). O apelo irresistível da causa da mulher reaparece no fim do volume. Nota intitulada "Aos leitores", parcialmente transcrita no segundo item deste texto, dá conta das fontes usadas e confessa que o ponto de partida foi pesquisa centrada na figura de Joaquim Nabuco, oportunidade em que Ana Maria Machado descobriu a "dimensão hipnotizante de Eulália" (p.222). Daí o livro, nas palavras da autora, "apenas uma obra de ficção, inspirada em suas vidas. Tomei a liberdade de imaginar cenas, ainda que procurasse jamais agredir a História e, sempre que possível, aproveitar palavras que eles mesmos deixaram registradas." (p. 221) Explicita-se portanto, nesse elemento paratextual, o modo adotado pela escritora de perceber e figurar o diálogo da ficção com a história.

A atenção dedicada a Nabuco, que ocupa espaço alongado na narrativa, pode ser explicada por seu papel nesse ponto de partida, somado à disponibilidade de material de pesquisa. Diga-se, entre parênteses, que não se pode deixar de notar que o clímax da narrativa está situado no momento da abolição, sem a presença da protagonista.

Retornando à revelação representada pela figura de Eulália: o resultado de tal hipnose é um romance que se pode qualificar como realista, no sentido da preservação da mediania crível tanto na caracterização do ser humano como no plano das ações. Tal contenção está antecipada na epígrafe, constituída por uma fala da personagem Rick, extraída do roteiro do filme Casablanca, de Julius e Philip Epstein e Howard Koch: “ - Ilsa, não sou muito bom nisso de ter gestos nobres, mas dá pra ver que os problemas de três pessoazinhas não valem um tostão furado neste mundo maluco. Um dia você vai entender isso" (MACHADO, 2015, s/p.). Esse tom terra-a-terra, sem grandiloquência, marca o discurso, seja na narração dos fatos, seja na caracterização das personagens. O par amoroso, sem que se negue a paixão exacerbada, é apresentado como muito humano, ele com seus jogos de sedução e conquista, mirando tanto Eulália como muitas outras, ela com seus ciúmes. Mas essas questões apenas ocasionam rusgas e separações temporárias. O que de fato impede que cheguem ao casamento, tantas vezes combinado para logo se desfazer o trato, da parte dela é a recusa em deixar suas atividades financeiras, de modo a acompanhar o marido, conforme atividades profissionais e interesses políticos dele. Da parte do homem, a incapacidade de entender que uma esposa pudesse ter um trabalho que exigisse que tivesse um escritório próprio, em lugar específico, impedindo-a de acompanhar o cônjuge.
Volume com pouco mais de duas centenas de páginas, a narrativa é dividida em 30 capítulos numerados, cujos títulos são constituídos pela indicação de local e ano em que ocorre a ação, temporalidade e espacialidade se espelhando, segurando o leitor com mão precisa. A narrativa segue quase linearmente, ainda que os intervalos de tempo sejam irregulares, com poucas evocações ao passado, limitadas às explicações indispensáveis para a compreensão das razões para as personagens se encontrarem nesse momento e serem como são. A exceção se dá no segundo capítulo, datado de "Pernambuco, 1857" (MACHADO, 2015, p. 11), um flashback, uma vez que a abertura, ponto de partida da linha temporal que será seguida, se dá no porto, "Rio de Janeiro, 1873" (p.7), hora do embarque em que ela está de mudança para Paris e ele segue para a Europa em viagem de estudos. Dá-se aí o primeiro contato e logo o namoro, que imediatamente encontra a acirrada oposição da irmã Chiquinha. Ele é Quincas, ela Zizinha. O uso de alcunhas, só mais adiante aparecendo nomes e sobrenomes, contribui para ilustrar o clima de familiaridade. Entretanto, as sugestões de contatos íntimos são bastante raras. As cenas que focalizam o casal, em vários lugares da Europa, são quase sempre passeios ao ar livre. Só na temporada em Petrópolis, já em 1885, refere-se a coabitação no quarto de hotel.

Narrativa predominantemente em terceira pessoa, o foco varia em três capítulos, graficamente diferenciados pelo uso do itálico. Em dois o leitor reconhece a voz dela e em um a dele, recurso para caracterizar o modo de ser e pensar de cada um. Narrador posicionado no presente da escrita, não se furta de opinar, de manifestar dúvida quanto à fidedignidade das fontes, em expressões como "há quem diga" (MACHADO, 2015, p. 192) ou "como muitos contam" (p. 209), de confrontar os hábitos da época narrada e os contemporâneos da narrativa, de analisar a sociedade, especialmente quanto à condição e ao papel da mulher. Esse aspecto tão didático, quase panfletário, encontra contraface em breve evocação a plano mágico, com a presença de divindades afro-brasileiras, que se preocupam com os protagonistas e tentam protegê-los, em passagens como:

Da vastidão das águas, Iemanjá olhava seu menino, agora crescido. Por perto, Ogum, orixá guerreiro, a observava. Entre protetor e implicante, parecia querer dizer algo. Talvez:

- Esse rapaz é um guerreiro. Não é só você que o protege. Eu também procuro estar por perto, ele é do bem e vai precisar. Mas é muito orgulhoso, altivo demais, nem toma conhecimento de nossa existência, não nos dá qualquer importância. Não me respeita nada. Ás vezes, bem que tenho vontade de lhe dar uma lição. Mostrar a ele que manda. Que tal nos juntarmos agora para dar um susto nele? 
O vento girou diferente, trazendo para perto Iansã, senhora das tempestades.

- De jeito nenhum. Agora não. Podem fazer com ele o que quiserem. Eu não me importo. Mas essa moça é minha. Dela cuido eu. Jamais uma tormenta lhe fará mal. Não permitirei (MACHADO, 2015, p. 35-36).

Passagens como essa, cuja rarefação é acentuada pelas suposições da voz narrativa - 'parecia querer dizer", "talvez" - funcionam como rápida distração, alívio para o peso da realidade, marcada pela impossibilidade de realização afetiva. A força dos padrões sociais é mais forte do que qualquer paixão humana ou proteção extraterrena. A oposição familiar é representada especialmente pela irmã. Nessa narrativa, é ela quem dá a ideia do subterfúgio de inventarem que houve a promessa, no leito de morte do pai, de não se casarem e ficarem juntas, como forma de as duas se furtarem à imposição do tio de contraírem núpcias com os primos. Depois Chiquinha passa a crer na própria mentira e tortura Zizinha com a cobrança à fidelidade ao juramento que não existiu. Essa irmã, deficiente e dependente, é uma força impositiva, tem delineamento psicológico bem definido, mas é sobretudo simbólica como representante do oponente, do impedimento.

A força do símbolo tem o poder de se perpetuar além do desaparecimento terreno. Francisca morre três décadas antes de Eulália. O percurso desta, exceto quanto à multiplicação dos bens, parece não se alterar com esse desaparecimento. No Epílogo, dedicado ao testamento e ao destino da fortuna, a atividade econômica aparece mais detalhadamente do que no desenrolar do enredo. Resta a Casa da Hera "transformada em museu. Conta a história de uma época. Com todos os móveis e objetos. [...] Todas as lembranças, premonições e esquecimentos. De um tempo que ajudou a mudar o tempo que viria depois" (MACHADO, 2015, p. 220).

Tempo em que o interesse em biografias se confessa sem subterfúgios, tempo em que os escritores de ficção referem fontes históricas explicitamente e se apropriam de personagens referenciais sem disfarces.

\section{Para concluir}

Nos dois romances, seja na figuração idealizada de Claudia Lage, seja na figuração realista de Ana Maria Machado, a impossibilidade de final feliz não decorre apenas de ações externas. São os valores arraigados nos próprios amantes que se impõem e os condenam. A mulher, emancipada financeiramente, situação extraordinária no contexto, não consegue abrir mão dos valores capitalistas da classe a que pertence. O político liberal e abolicionista, porta-voz da ideologia mais avançada da época, não é capaz de renunciar à posição de cabeça do casal. Naquele momento e naquela sociedade, não há autonomia feminina possível, ainda que a custo da realização afetiva. A posição da mulher é inapelavelmente de vítima, seja pela sujeição ao marido e à família, seja pela submissão aos valores de classe.

Vale observar ainda que são dois romances biográficos, históricos, escritos por mulheres. Se a presença feminina na cena literária contemporânea já não é um fenômeno que precise ser festejado, a autoria feminina de romances históricos é bastante recente. Nada a estranhar que mulheres escrevam sobre mulheres, bem como que romances versem sobre relações amorosas. Também não cabe cobrar o que a criação não faz, não se propõe a fazer. No entanto, é de notar que, quando chegam a merecer registro, são vagos os comentários sobre atividades de Eufrásia Teixeira Leite como profissional do universo financeiro. $\mathrm{O}$ mesmo não acontece quanto à atuação de Joaquim Nabuco, como jurista, como político, como orador, como diplomata. Pode-se usar, como argumento, que sobre ele existe grande disponibilidade de material de pesquisa. Mas, afora o fato de o romance não depender de apoio documental, a essa razão é possível contrapor que, justamente por se tratar de figura e de fatos corriqueiros nos estudos históricos, não haveria motivação para receber tanto espaço na ficção. Uma mulher, brasileira, ser financista na época é o fenômeno singular, o diferencial, do ponto de vista histórico.

Ainda vale observar que, nos textos de caráter informativo e histórico, quando se trata de Joaquim Nabuco, a paixão por Eulália Teixeira Leite pode ser citada, como uma curiosidade da vida afetiva do grande cidadão. Já a relação amorosa avulta e se sobrepõe quando ela é a focalizada. De início se anunciou que não se intentava, nesta abordagem, paralelismo entre texto biográfico e ficcional com o intuito de conferir datas e fatos. Mas não se pode deixar de notar que a presença de Nabuco é forte não apenas nos romances. Afinal, o amor é matéria romanesca por excelência, com larga vantagem sobre o universo das finanças. Entretanto, não encontrei texto sobre Eulália que não fizesse referência a Nabuco, nunca eventual. $\mathrm{O}$ inverso não acontece. Não se nega o papel de Joaquim Nabuco na história do Brasil. Seu nome pode aparecer, como aparece nos estudos históricos abrangentes citados, em listagens mais ou menos extensas, nomeando brasileiros com atuação significativa no cenário da época. Ele tem pares. Quantos brasileiros, mesmo sem considerar se homens ou mulheres, atuaram nas finanças internacionais e amealharam fortuna de vulto, ainda que apenas aproximada, na passagem do século XIX para o $\mathrm{XX}$ ? A listagem que acolheria o nome de Eulália Teixeira Leite talvez tenha uma única linha.

Ao romance não cabe concorrer com a história, com a biografia. No entanto, a desenvoltura com que pode 
comerciar com o imaginário alcança chamar a atenção para vazios desta.

\section{Referências}

ARFUCH, Leonor. El espacio biográfico: dilemas de la subjetividad contemporánea. Buenos Aires: Fondo de Cultura Económica, 2002.

DOSSE, François. $O$ desafio biográfico: escrever uma vida. Trad. Gilson César Cardoso de Souza. São Paulo: Editora da Universidade de São Paulo, 2009.

FERNANDES, Neusa. Eufrásia e Nabuco. Rio de Janeiro: Mauad X, 2012.

LAGE, Claudia. Mundos de Eufrásia: a história de amor entre a incrível Eufrásia Teixeira Leite e o notável Joaquim Nabuco. Rio de Janeiro: Record, 2009.
LOPEZ, Adriana; MOTA, Carlos Guilherme. História do Brasil: uma interpretação. São Paulo: Editora Senac São Paulo, 2008.

MACHADO, Ana Maria. Um mapa todo seu. Rio de Janeiro: Objetiva, 2015.

SCHWARCZ, Lilia M.; STARLING, Heloisa M. Brasil: uma biografia. São Paulo: Companhia das Letras, 2015.

WOOLF, Virginia. Um teto todo seu. Trad. Vera Ribeiro. Rio de Janeiro: Nova Fronteira, 1985.

Recebido: $13 / 01 / 2018$

Aprovado: 20/01/2018

Contato:

Marilene Weinhardt <mweinhardt@gmail.com>

ORCID: <https://orcid.org/0000-0003-2825-6959> 